\title{
PENGARUH BIAYA PRODUKSI TERHADAP LABA BERSIH PADA PERUSAHAAN MANUFAKTUR SUBSEKTOR MAKANAN DAN MINUMAN YANG TERDAFTAR DI BEI PERIODE 2019-2020
}

\author{
Marismiati, Agung Azhar Ziddan \\ Program Studi D4 Akuntansi Keuangan, Politeknik Pos Indonesia \\ Marismiati03@gmail.com, agungazhard7@gmail.com
}

\begin{abstract}
ABSTRAK
Perusahaan Makanan dan Minuman merupakan perusahaan manufaktur, yaitu industri pengolahan yang mengolah bahan baku menjadi barang setengah jadi atau barang jadi. Perusahaan manufaktur identik dengan pabrik yang menggunakan mesin-mesin, peralatan dan tenaga kerja. Biaya-biaya yang dikeluarkan oleh perusahaan manufaktur diantaranya yaitu biaya produksi. Tujuan dari perusahaan manufakur sendiri yaitu untuk memperoleh laba bersih yang sebesar-besarnya. Penelitian ini bertujuan untuk mengetahui apakah ada pengaruh Biaya Produksi terhadap Laba Bersih pada Perusahaan Manufaktur Subsektor Makanan dan Minuman yang terdaftar di BEI periode 2019-2020. Data yang digunakan pada penelitian ini yaitu data sekunder. Sampel yang digunakan dalam penelitian ini yaitu laporan keuangan laba rugi dan catatan atas laporan keuangan Perusahaan Manufaktur Subsektor Makanan dan Minuman yang terdaftar di BEI periode 2019-2020. Penelitian ini merupakan penelitian kuantitatif. Penelitian ini menggunakan sumber data sekunder. Hipotesis yang ditetapkan yaitu uji dua pihak. Teknik analisis yang digunakan statistik deskriptif, korelasi product moment, analisis regresi linier sederhana, analisis koefisien determenasi, dan uji t. Pada uji koefisien determinasi, biaya produksi berpengaruh sebesar $88,5 \%$ terhadap laba bersih dan sisanya 11,5\% dipengaruhi oleh faktor lain yang tidak penulis teliti. Uji $\mathrm{t}$ menghasilkan $\mathrm{t}_{\text {hitung }} 16,707>\mathrm{t}_{\text {tabel }} 2,028$ dengan signifikansi $0,000(0,000<0,05)$ artinya terdapat pengaruh yang signifikan antara biaya produksi terhadap laba bersih pada perusahaan manufaktur subsektor makanan dan minuman yang terdaftar di BEI periode 2019-2020
\end{abstract}

Kata Kunci: Biaya Produksi, Laba Bersih dan Perusahaan Manufaktur.

\begin{abstract}
Food and Beverage Company is a manufacturing company, namely a processing industry that processes raw materials into semi-finished goods or finished goods. Manufacturing companies are identical with factories that use machines, equipment and labor. The costs incurred by manufacturing companies include production costs. The purpose of the manufacturing company itself is to obtain the maximum net profit. This study aims to determine whether there is an effect of Production Costs on Net Profits in Food and Beverage Subsector Manufacturing Companies listed on the IDX for the 2019-2020 period. The data used in this study is secondary data. The samples used in this study are the financial statements of income and notes to the financial statements of Manufacturing Companies in the Food and Beverage Subsector listed on the IDX for the 2019-2020 period. This research is a quantitative research. This study uses secondary data sources. The established hypothesis is a two-party test. The analysis technique used was descriptive statistics, product moment correlation, simple linear regression analysis, coefficient of determination analysis, and t test. In the coefficient of determination test, production costs have an effect of $88.5 \%$ on net income and the remaining $11.5 \%$ is influenced by other factors that the author does not examine. The t test produces t count 16,707 > t table 2,028 with a significance of $0.000(0.000<0.05)$ meaning that there is a significant effect
\end{abstract}


between production costs and net income in food and beverage sub-sector manufacturing companies listed on the Indonesia Stock Exchange for the 2019-2020 period.

Keywords: Production Cost, Net Profit and Manufacturing Company.

\section{PENDAHULUAN}

Industri manufaktur pada saat ini terus mengalami peningkatan sehingga industri manufaktur dapat mempengaruhi perekonomian negara Indonesia. Apalagi perusahaan manufaktur sektor makanan dan minuman yang tak henti-hentinya berkembang secara terus-menerus. Hal tersebut terjadi karena makanan dan minuman merupakan produk konsumtif bagi seluruh masyarakat.

Perusahaan manufaktur merupakan perusahaan yang mengolah produknya dari nol sampai menjadi produk jadi yang siap untuk dijual. Tujuan dari perusahaan manufaktur juga yaitu mengolah bahan baku yang dikelola menjadi suatu produk untuk memenuhi kebutuhan pasar. Produk tersebut kemudian diperjualbelikan kepada masyarakat luas dan menjadi konsumsi masyarakat sehingga perusahaan dapat memperoleh laba dari aktivitas tersebut.

Menurut (Hery, 2017) laba bersih (net income) adalah transaksi pendapatan, beban, keuntungan dan kerugian. Transaksi tersebut diikhtisarkan dalam laporan laba rugi. Sedangkan menurut (Sujarweni, 2017) laba bersih adalah angka terakhir dari perhitungan laba rugi yang didapatkan dari laba operasi ditambah pendapatan lain-lain dikurangi dengan beban lain-lain.

Dikutip dari (Julian, 2021) mengatakan Kinerja PT. Garudafood Putra Putri Jaya Tbk (GOOD) di tahun 2020 kurang menggembirakan. Laba bersih GOOD di tahun 2020 pun anjlok 43,75\% menjadi Rp 245,10 miliar di semester I 2020. Asal tahu saja, laba bersih GOOD pada tahun lalu atau 2019 mencapai Rp 435,766 miliar.

Kemudian dikutip dari (Ningsih, 2021) mengatakan PT Multi Bintang Indonesia Tbk (MLBI) kehilangan banyak keuntungan sepanjang tahun 2020. Perusahaan yang menjual minuman bermerek Bir Bintang ini mencetak penurunan laba bersih sedalam 76,30\% dari Rp1,21 triliun pada Desember 2019 menjadi Rp285,67 miliar pada Desember 2020 .

Kemudian dikutip dari (Hidayat, 2021) mengatakan produsen bahan makanan PT Sekar Laut Tbk (SKLT) membukukan pendapatan neto sebesar Rp 1,25 triliun pada tahun 2020. Angka ini turun 2,34\% (yoy) dibandingkan realisasi pendapatan neto SKLT di tahun 2019 sebesar Rp 1,28 triliun. SKLT meraup laba bersih yang dapat didistribusikan kepada pemilik entitas induk sebesar Rp 42,52 miliar pada tahun 2020. Jumlah ini turun 5,46\% (yoy) dibandingkan laba bersih SKLT di tahun 2019 sebanyak Rp 44,98 miliar.

\section{Tabel 1.1}

Data Laba Bersih Perusahaan Manufaktur Subsektor Makanan dan Minuman yang terdaftar di BEI 2019-2020

\begin{tabular}{|c|c|c|c|c|c|c|}
\hline Perusahaan & Periode & \multicolumn{2}{|c|}{ Nilai Laba Bersih } & \multicolumn{2}{|r|}{ Perubahan } & $\%$ \\
\hline \multirow[t]{2}{*}{ GOOD } & 2019 & & 435.766 .359 .480 & \multirow{2}{*}{\multicolumn{2}{|c|}{-Rp $\quad 89.210 .324 .849$}} & \multirow[t]{2}{*}{$-43,75 \%$} \\
\hline & 2020 & $\mathrm{Rp}$ & 245.103 .761 .907 & & & \\
\hline \multirow[t]{2}{*}{ MLBI } & 2019 & $\mathrm{Rp}$ & 1.206 .059 & \multirow[t]{2}{*}{$-\mathrm{Rp}$} & \multirow[t]{2}{*}{920.442} & \multirow[t]{2}{*}{$76,30 \%$} \\
\hline & 2020 & $\mathrm{Rp}$ & 285.617 & & & \\
\hline \multirow[t]{2}{*}{ SKLT } & 2019 & $\mathrm{Rp}$ & 44.943 .627 .900 & \multirow[t]{2}{*}{$-R p$} & \multirow[t]{2}{*}{2.423 .381 .178} & \multirow[t]{2}{*}{$5,46 \%$} \\
\hline & 2020 & $\mathrm{Rp}$ & 42.520 .246 .722 & & & \\
\hline
\end{tabular}

Sumber:www.idx.co.id, diolah sendiri

Untuk menjalankan sebuah perusahaan, maka perusahaan harus mengeluarkan biaya untuk operasional perusahaannya agar mendapat laba. (Sujarweni, 2017) 
mengemukakan bahwa "faktor-faktor yang mempengaruhi laba bersih adalah biaya, harga jual, dan volume penjualan". Apalagi untuk perusahaan manufaktur biaya-biaya yang dikeluarkan tidak sedikit. Perusahaan manufaktur perlu mengeluarkan biaya untuk membeli bahan baku, mengeluarkan biaya untuk overhead pabrik serta biaya untuk membayar upah karyawan atau tenaga kerja untuk mengolah bahan baku sehingga kegiatan tersebut disebut biaya produksi.

Menurut (Sujarweni, 2019) "biaya adalah pengorbanan sumber ekonomi yang diukur dalam satuan uang dalam usahanya mendapatkan sesuatu untuk mencapai tujuan tertentu baik yang sudah terjadi dan belum terjadi atau baru direncanakan". Menurut (Mulyadi, 2017) "dalam perusahaan manufaktur, biaya dikelompokkan menjadi tiga kelompok yaitu biaya produksi, biaya pemasaran dan biaya administrasi dan umum". Menurut (Mulyadi, 2017) "biaya produksi adalah biaya-biaya yang terjadi untuk mengolah bahan baku menjadi produk jadi yang siap untuk dijual". Kemudian menurut (Harnanto, 2017) "biaya produksi dianggap melekat pada penentuan laba rugi suatu perusahaan, karena biaya produksi diperlakukan sebagai beban atas pendapatan".

Penelitian yang dilakukan oleh (Felicia, 2018) yang berjudul Pengaruh Biaya Produksi, Biaya Kualitas dan Biaya Promosi Terhadap Laba Bersih Pada Perusahaan Manufaktur yang terdaftar di Bursa Efek Indonesia Periode 2013-2015 menyimpulkan bahwa secara simultan, biaya produksi, biaya kualitas dan biaya promosi berpengaruh signifikan terhadap laba bersih pada perusahaan manufaktur yang terdaftar di Bursa Efek Indonesia periode 2013-2015. Sedangkan Secara parsial, biaya produksi, biaya kualitas dan biaya promosi berpengaruh positif terhadap laba bersih pada perusahaan manufaktur yang terdaftar di Bursa Efek Indonesia periode 2013-2015.

Selanjutnya penelitian yang dilakukan oleh (Y Casmadi, 2019) yang berjudul Pengaruh Biaya Produksi dan Biaya Operasional terhadap Laba Bersih pada PT. Ultrajaya Milk Industry dan Trading Company Tbk menyimpulkan bahwa Biaya Produksi berpengaruh negatif terhadap dan signifikan terhadap laba bersih pada PT. Ultrajaya Milk Industry dan Trading Company Tbk.

Kemudian penelitian yang dilakukan oleh (Sanjaya, 2020) yang berjudul Pengaruh Biaya Produksi, Biaya Promosi dan Volume Penjulan terhadap Laba Pada Perusahaan Manufaktur yang Terdaftar di Bursa Efek Indonesia Periode Tahun 2015-2017 menyimpulkan bahwa biaya produksi berpengaruh positif signifikan terhadap laba perusahaan. Maka dengan meningkatnya biaya produksi dengan marginal tambahan biaya lebih kecil dibandingkan marginal tambahan volume maka laba akan meningkat pada perusahaan manufaktur di Bursa Efek Indonesia tahun 2015-2017.

Penelitian ini bertujuan untuk mengetahui bagaimana kenaikan dan penurunan biaya produksi dan laba bersih serta pengaruh biaya produksi terhadap laba bersih pada perusahaan manufaktur subsektor makanan dan minuman periode 2019-2020.

\section{Kajian Pustaka}

\section{Biaya Produksi}

Menurut (Mulyadi, 2018) "biaya produksi merupakan biaya-biaya yang terjadi untuk mengolah bahan baku menjadi produk jadi yang siap untuk dijual”.

Menurut (Mulyadi, 2018) menurut objek pengeluarannya secara garis besar biaya produksi ini dibagi menjadi tiga yaitu, biaya bahan baku, biaya tenaga kerja langsung dan biaya overhead pabrik (factory overhead cost).

Sedangkan menurut (Harnanto, 2017) "biaya produksi dianggap melekat pada penentuan laba rugi suatu perusahaan, karena biaya produksi diperlakukan sebagai beban atas pendapatan". 
Biaya Produksi menurut objek pengeluarannya secara garis besar biaya produksi ini dibagi menjadi tiga yaitu, biaya bahan baku, biaya tenaga kerja langsung dan biaya overhead pabrik (factory overhead cost) (Mulyadi, 2018)

\section{Laba Bersih}

Menurut (Amin, 2018) "laba bersih berasal dari transaksi pendapatan, beban, keuntungan dan kerugian. Transaksi ini diikhtisarkan dalam laporan laba rugi. Akuntan telah mengadopsi pendekatan transaksi dalam mengukur laba atau rugi bersih, yang menekankan pada perhitungan langsung antara pendapan, beban, keuntungan dan kerugian. Pendekatan transaksi ini, kadang dikenal sebagai metode penandingan (matching method)".

Menurut (Hery, 2017) "laba bersih (net income) adalah transaksi pendapatan, beban, keuntungan dan kerugian. Transaksi tersebut diikhtisarkan dalam laporan laba rugi".

Menurut (Sujarweni, 2017) "laba bersih adalah angka terakhir dari perhitungan laba rugi yang didapatkan dari laba operasi ditambah pendapatan lain-lain dikurangi dengan beban lain-lain".

Indikator laba bersih Menurut (Hery, 2017) adalah sebagai berikut:

Laba Bersih = Laba Sebelum Pajak - Pajak Penghasilan

\section{METODE PENELITIAN}

Dalam penelitian ini peneliti menggunakan metode penelitian kuantitatif asosiatif yang bersifat kausal.

\section{Teknik Pengumpulan Data}

Teknik pengumpulan data pada penelitian ini yaitu dengan menggunakan data sekunder. Data diperoleh dari website Bursa Efek Indonesia (BEI) dan website perusahaan yaitu berupa laporan keuangan perusahaan manufaktur subsektor makanan dan minuman periode 2019-2020.

\section{Teknik Sampling}

Teknik sampling pada penelitian ini menggunakan Teknik nonprobability sampling dan teknik pengambilan sampel yang digunakan adalah sampling purposive.

Sampel yang di ambil adalah sampel yang sesuai dengan variabel yaitu mengenai variabel biaya produksi (X) dan laba bersih (Y) yang terdapat pada laporan keuangan.

\section{Teknik Analisis Data}

Teknik analisis data dalam penelitian ini menggunakan analisis statistik deskriptif, Analisis Korelasi Product Moment, Analisis Regresi Linear Sederhana, Koefisien Determinasi dan Uji t.

\section{HASIL DAN PEMBAHASAN}

\section{Statistik Deskriptif}

Kenaikan biaya produksi paling tinggi terjadi pada PT Sekar Bumi Tbk (SKBM) sebesar 47,87\% atau Rp.952.269.535.589. Sedangkan penurunan biaya produksi paling tinggi terjadi pada PT Buyung Poetra Sembada (HOKI) sebesar 27,20\% atau Rp.384.6 48.347.721. Kenaikan biaya produksi paling tinggi terjadi pada PT Sekar Bumi Tbk (SKBM) sebesar 47,87\% atau Rp.952.269.535.589. Sedangkan penurunan biaya produksi paling tinggi terjadi pada PT Buyung Poetra Sembada (HOKI) sebesar 27,20\% atau Rp.384.6 48.347.721.

\section{Analisis Korelasi Product Moment}

Tabel 4.1

Analisis Korelasi Product Moment

\section{Correlations}

\begin{tabular}{llr|r} 
& \multicolumn{2}{c}{$\begin{array}{c}\text { Biaya } \\
\text { Produksi }\end{array}$} & Laba Bersih \\
\hline Biaya Produksi & Pearson Correlation & 1 & $.941^{* *}$ \\
\cline { 2 - 4 }
\end{tabular}




\begin{tabular}{llr|r}
\hline & Sig. (2-tailed) & 38 & .000 \\
\cline { 2 - 4 } & $\mathrm{N}$ & $.941^{* *}$ & 38 \\
\hline \multirow{2}{*}{ Laba Bersih } & Pearson Correlation & .000 & 1 \\
\cline { 2 - 4 } & Sig. (2-tailed) & 38 & 38 \\
\cline { 2 - 4 } & $\mathrm{N}$ & \\
\hline
\end{tabular}

**. Correlation is significant at the 0.01 level (2-tailed).

Dari hasil pengujian analisis korelasi product moment diatas, maka didapatkan $\mathrm{R}_{\text {hitung }}$ sebesar 0,941 dan $\mathrm{R}_{\text {tabel }}$ sebesar 0,329. Jadi dapat disimpulkan bahwa $\mathrm{R}_{\text {hitung }} 0,941>$ $\mathrm{R}_{\text {tabel }} 0,329$, yang berarti bahwa terdapat hubungan antara biaya produksi terhadap laba

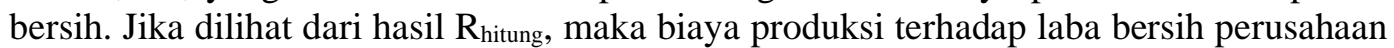
manufaktur subsektor makanan dan minuman periode 2019-2020 berada pada interpretasi 0,80-1,00 artinya bahwa biaya produksi terhadap laba bersih memiliki hubungan yang sangat kuat.

\section{Analisis Regresi Linear Sederhana}

Tabel 4.2

Analisis Regresi Linear Sederhana Coefficients $^{\mathrm{a}}$

\begin{tabular}{|c|c|c|c|c|c|c|}
\hline & \multicolumn{6}{|c|}{ Coefficients } \\
\hline \multirow[b]{2}{*}{ Model } & & \multicolumn{2}{|c|}{ Unstandardized Coefficients } & $\begin{array}{l}\text { Standardized } \\
\text { Coefficients }\end{array}$ & & \\
\hline & & $\mathrm{B}$ & Std. Error & Beta & $\mathrm{t}$ & Sig. \\
\hline 1 & (Constant) & $\begin{array}{r}111936089822 \\
.335\end{array}$ & $\begin{array}{r}131689290354 \\
.341\end{array}$ & & .850 & .401 \\
\hline & Biaya Produksi & .152 & .009 & .941 & 16.707 & .000 \\
\hline
\end{tabular}

a. Dependent Variable: Laba Bersih

Dapat dilihat dari tabel diatas, hasil yang didapatkan dari analisis regresi linier sederhana nilai konstan sebesar 111936089822,335 dan nilai regresinya sebesar 0,152.

\section{Analisis Koefisien Determinasi}

\section{Tabel 4.3}

Koefisien Determinasi Model Summary

\begin{tabular}{lr|r|r|r} 
Model & R & R Square & $\begin{array}{c}\text { Adjusted R } \\
\text { Square }\end{array}$ & $\begin{array}{c}\text { Std. Error of } \\
\text { the Estimate }\end{array}$ \\
\hline 1 & $.941^{\mathrm{a}}$ & .886 & .883 & 724316331934 \\
& & & & .045 \\
\hline
\end{tabular}

a. Predictors: (Constant), Biaya Produksi

Dapat dilihat dari hasil perhitungan diatas, dapat diketahui bahwa koefisien determinasi memiliki nilai 0,941 dan Rsquare sebesar 0,886 atau $88,5 \%$.

\section{Uji t}

Tabel 4.4

Analisis Uji t

Coefficients $^{\mathrm{a}}$

\begin{tabular}{|c|c|c|c|c|c|c|}
\hline \multirow[b]{2}{*}{ Model } & & \multicolumn{2}{|c|}{ Unstandardized Coefficients } & \multirow{2}{*}{$\begin{array}{c}\text { Standardized } \\
\text { Coefficients } \\
\text { Beta } \\
\end{array}$} & \multirow[b]{2}{*}{$\mathrm{T}$} & \multirow[b]{2}{*}{ Sig. } \\
\hline & & B & Std. Error & & & \\
\hline 1 & (Constant) & $\begin{array}{r}111936089822 \\
.335\end{array}$ & $\begin{array}{r}131689290354 \\
.341\end{array}$ & & .850 & .401 \\
\hline & Biaya Produksi & .152 & .009 & .941 & 16.707 & .000 \\
\hline
\end{tabular}


a. Dependent Variable: Laba Bersih

Dilihat dari hasil analisis uji $t$ diatas dapat diketahui $t_{\text {hitung }}$ sebesar 16.707. Jika diinterpretasikan dengan $\mathrm{t}_{\text {tabel }}$ maka harus diketahui derajat kebebasan $(\mathrm{dk})=\mathrm{n}-\mathrm{k}(38-2)$ sebesar 36 dan $t_{\text {tabel }}$ sebesar 2,028. Dapat diketahui $t_{\text {hitung }}$ 16.707> $t_{\text {tabel }} 2,028$ dengan signifikansi $0,000(0,000<0,05)$ artinya terdapat pengaruh yang signifikan antara biaya produksi terhadap laba bersih pada perusahaan manufaktur subsektor makanan dan minuman yang terdaftar di BEI periode 2019-2020. Maka kurvanya sebagai berikut:

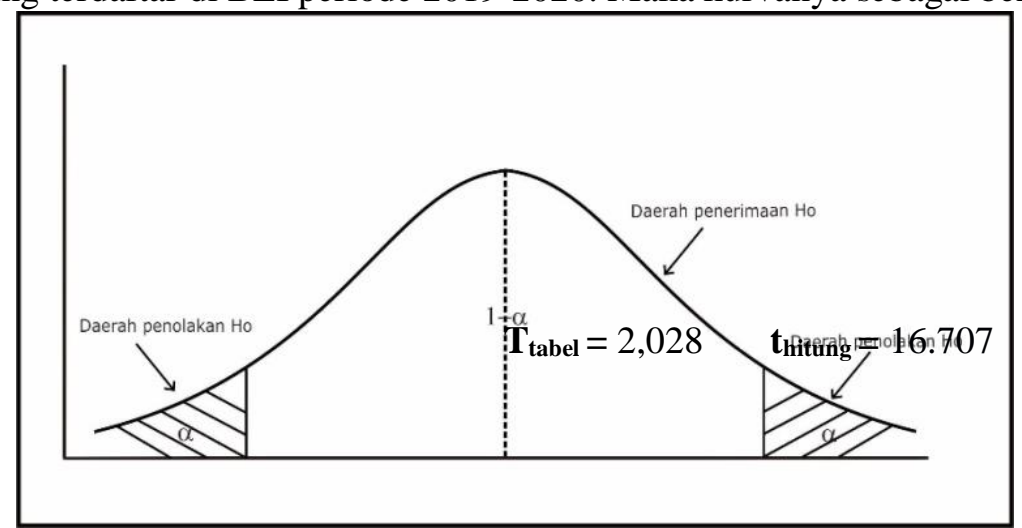

Gambar 4.1 Kurva Penerimaan dan Penolakan Ho

\section{KESIMPULAN DAN SARAN}

\section{Kesimpulan}

Berdasarkan dari analisis yang dilakukan pada bab sebelumnya, penelitian dengan judul "Pengaruh Biaya Produksi terhadap Laba Bersih pada Perusahaan Manufaktur Subsektor Makanan dan Minuman yang terdaftar di BEI periode 2019-2020" dapat disimpulkan bahwa:

Biaya produksi dan laba bersih pada tahun 2019-2020 ada yang mengalami kenaikan dan penurunan. Biaya Produksi berpengaruh secara signifikan terhadap Laba Bersih pada perusahaan manufaktur subsektor makanan dan minuman periode 2019-2020.

\section{Saran}

1. Saran Teoritis

Penelitian ini diharapkan dapat memberikan tambahan pengetahuan, sebagai sumber informasi dan sebagai sumbangan pemikiran dalam mengembangkan ilmu akuntansi keuangan, serta berkontribusi dalam pengembangan penelitian khususnya mengenai Biaya Produksi terhadap Laba Bersih serta sebagai masukan dan tambahan referensi bagi para pembaca khususnya dalam ilmu ekonomi.

2. Saran Praktis

a. Bagi Perusahaan

Besarnya biaya produksi dapat mempengaruhi laba bersih. Oleh karena itu perusahaan manufaktur subsektor makanan dan minuman hendaknya terus berupaya untuk melakukan kebijakan-kebijakan yang dapat meningkatkan laba dari kegiatan produksi perusahaan yaitu biaya produksi dengan cara efesiensi bahan baku produksi dan hal-hal lainnya yang akan berdampak pada laba bersih. Perusahaan manufaktur subsektor makanan dan minuman juga hendaknya untuk lebih mengalokasikan biaya produksi yang lebih besar, sehingga dari biaya produksi tersebut perusahaan dapat meningkatkan jumlah laba bersih

b. Bagi Peneliti Selanjutnya 
Bagi penelitian selanjutnya diharapkan menambah sampel dan memperluas populasi untuk mendapatkan hasil yang lebih akurat, serta menambah variabel-variabel yang lain terkait dengan laba bersih

\section{DAFTAR PUSTAKA}

Felicia, G. R. (2018). Pengaruh Biaya Produksi, Biaya Kualitas dan Biaya Promosi Terhadap Laba Bersih Pada Perusahaan Manufaktur yang Terdaftar di Bursa Efek Indonesia Periode 2013-2015. Jurnal Ilmu Manajemen METHONOMIX.

Harnanto. (2017). Akuntansi Biaya - Sistem Biaya Historis. C.V ANDI OFFSET.

Hery. (2017). Teori Akuntansi Pendekatan Konsep dan Analisis. PT. Grasindo.

Hidayat, K. (2021). Pendapatan bersih Sekar Laut (SKLT) turun menjadi Rp 1,25 triliun di tahun lalu. Kontan.Co.Id. https://industri.kontan.co.id/news/pendapatan-bersihsekar-laut-sklt-turun-menjadi-rp-125-triliun-di-tahun-lalu

Julian, M. (2021). Laba Bersih anjlok 40\%, kinerja Garodafood (Good) di semester I-2020 mengecewakan. Kontan.Co.Id. https://investasi.kontan.co.id/news/laba-bersihanjlok-40-kinerja-garudafood-good-di-semester-i-2020-mengecewakan

Mulyadi. (2017). Akuntansi Biaya Edisi 5. Sekolah Tinggi Ilmu Manajemen YKPN.

Mulyadi. (2018). Akuntansi Biaya Edisi 5. UPT STM YKPN.

Ningsih, L. (2021). Perusahaan Penjual Bir Meringis, Keuntungan Multi Bintang Anjlok Drastis! Warta Ekonomi.Co.Id. https://www.wartaekonomi.co.id/read331092/perusahaan-penjual-bir-meringiskeuntungan-multi-bintang-anjlok-drastis

Sanjaya, M. A. Y. dan I. K. P. W. (2020). Pengaruh Biaya Produksi, Biaya Promosi dan Volume Penjualan terhadap Laba Pada Perusahaan Manufaktur yang Terdaftar di Bursa Efek Indonesia Periode Tahun 2015-2017. Wacana Ekonomi (Jurnal Ekonomi, Bisnis Dan Akuntansi).

Sujarweni, V. . (2017). Analisis Laporan Keuangan : Teori, Aplikasi dan Hasil Penelitian. Pustaka Baru Press.

Sujarweni, V. . (2019). Akuntansi Biaya, In Mona (Ed). Pustaka Baru Press.

Y Casmadi, I. A. (2019). Pengaruh Biaya Produksi \& Biaya Operasional Terhadap Laba Bersih Pada PT. Ultrajaya Milk Industry \& Trading Company, Tbk. Jurnal Akuntansi. 